\title{
An In Vivo and In Vitro Study of the Mechanism of Prednisone-induced Insulin Resistance in Healthy Subjects
}

\author{
G. Pagano, P. Cavallo-Perin, M. Cassader, A. Bruno, A. Ozzello, P. Masciola, \\ A. M. DALL'OMO, and B. IMBIMBo, Institute of Internal Medicine, \\ University of Turin, 10126 Torino-Corso Polonia 14, Italy; \\ Lepetit Group spA, Milan, Italy
}

A B S T R A C T Prednisone-induced insulin resistance may depend on either reduced sensitivity (receptor defect) or reduced response to insulin (postreceptor defect). To clarify the mechanism of prednisone-induced insulin resistance, a $\left[{ }^{3} \mathrm{H}\right]$ glucose infusion $(1 \mu \mathrm{Ci} /$ min) was performed for 120 min before and during a euglycemic clamp repeated at $\sim 100, \sim 1,000$, and $\sim 10,000 \mu \mathrm{U} / \mathrm{ml}$ steady state plasma insulin concentration in 10 healthy, normal weight subjects, aged $35 \pm 7 \mathrm{yr}$. Each test was repeated after $7-\mathrm{d}$ administration of placebo or prednisone ( 15 plus $15 \mathrm{mg} / \mathrm{d}$ per subject), in a randomized sequence with an interval of 1 mo between the two tests. Mean fasting blood glucose $(89.5 \pm 2.1$ vs. $83.7 \pm 1.9 \mathrm{mg} / \mathrm{dl})$ and mean fasting plasma insulin values $(17.8 \pm 1.2$ vs. $14.3 \pm 0.8 \mu \mathrm{U} / \mathrm{ml})$ were significantly higher $(P<0.01)$ after prednisone. The insulin sensitivity index (glucose metabolic clearance rate in $\mathrm{ml} / \mathrm{kg}$ per $\mathrm{min})$ was significantly lower $(P<0.001)$ after prednisone at all three steady state plasma insulin levels: $2.8 \pm 0.3$ vs. $7.4 \pm 1.1$ at $\sim 100 \mu \mathrm{U} / \mathrm{ml} ; 6.0 \pm 0.5$ vs. $12.2 \pm 1.1$ at $\sim 1,000 \mu \mathrm{U} / \mathrm{ml} ; 7.4 \pm 0.6$ vs. $14.4 \pm 0.5$ at $\sim 10,000 \mu \mathrm{U} / \mathrm{ml}$. Fasting glucose production (in $\mathrm{mg} /$ kg per $\mathrm{min}$ ) was significantly higher after prednisone: $3.7 \pm 0.2$ vs. $2.9 \pm 0.2, P<0.001$. Suppression of glucose production at steady state plasma insulin level of $\sim 100$ $\mu \mathrm{U} / \mathrm{ml}$ was less after prednisone $(1.01 \pm 0.35$ vs. $0.14 \pm 0.13, \mathrm{NS})$, and total at $\sim 1,000$ and $\sim 10,000 \mu \mathrm{U} /$ $\mathrm{ml}$ after both prednisone and placebo. The metabolic kinetic parameters of insulin after prednisone were not significantly different from those after placebo. In addition, insulin binding and 3-ortho-methyl-glucose transport were studied in vitro on fat cells from 16 normal-weight surgical candidates aged $40 \pm 8$ yr (10

Received for publication 9 February 1983 and in revised form 28 July 1983. treated with placebo and 6 with prednisone as above). No significant difference was observed with regard to specific insulin binding (tested with $1 \mathrm{ng} / \mathrm{ml}$ hormone only), whereas significant transport differences were noted at the basal level $(0.40 \pm 0.10 \mathrm{vs.} 0.54 \pm 0.12 \mathrm{pmol} /$ $10^{5}$ cells, $\left.P<0.05\right)$, and at increasing concentrations up to the maximum stimulation values $(5 \mathrm{ng} / \mathrm{ml})$ : $0.59 \pm 0.04$ vs. $0.92 \pm 0.12 \mathrm{pmol} / 10^{5}$ cells, $P<0.005$. These results suggest that $(a)$ administration of an antiinflammatory dose of prednisone for $7 \mathrm{~d}$ induces insulin resistance in man; $(b)$ this is more dependent on depressed peripheral glucose utilization than on increased endogenous production; $(c)$ total insulin binding on isolated adipocytes is not significantly affected; $(d)$ insulin resistance is primarily the outcome of postreceptor defect (impaired glucose transport).

\section{INTRODUCTION}

Like other glucocorticoids (1-4), prednisone increases blood glucose in man (5). This effect is accompanied by hyperinsulinemia (insulin resistance) (6) that may be attributable to either reduced peripheral insulin sensitivity or increased hepatic glucose production (6). Different glucocorticoids, too, may exert a different metabolic effect on the hepatic and peripheral sites (4). It is not yet known whether this situation reflects reduced sensitivity (i.e., a receptor defect), a reduced response to insulin (i.e., a postreceptor defect), or both $(7,8)$. Since an increase in insulin binding by glucocorticoids was reported in vitro study, a postreceptor mechanism must be taken in consideration. Account must also be taken of the fact that glucocorticoids bind to specific cytoplasmatic receptors and influence cell metabolism through a second messenger $(9,10)$ that also seems to act at the nuclear level. The result is a control of protein synthesis, maybe including modulation of receptor protein and glucose carriers turnover. 
The first postreceptor step, in fact, is that related to the transmembrane transport of glucose. This step can now be investigated in man (11).

In vivo use of the euglycemic clamp enables an assessment of insulin action in the periphery and a provisional discrimination between reduced response and/ or reduced sensitivity to the hormone (12). Simultaneous examination of endogenous glucose production under basal conditions and during euglycemic-hyperinsulinemic clamp (13) offers quantification of the hepatic level of insulin resistance as well. Joint utilization of this technique in healthy subjects before and after an average antiinflammatory dose $(30 \mathrm{mg} / \mathrm{d})$ of prednisone should thus permit analysis of the mechanism whereby this corticosteroid induces insulin resistance.

\section{METHODS}

Subjects. Six male and four female healthy volunteers aged $35 \pm 7$ yr with no family history of diabetes mellitus, $94 \pm 3 \%$ ideal body weight, were studied after receiving a placebo or 15 plus $15 \mathrm{mg}$ (at 8 and $15 \mathrm{~h}$ ) prednisone tablets per $\mathrm{d}$ for $7 \mathrm{~d}$ in a random sequence. Six subjects repeated the test six times (three after placebo and three after prednisone) respectively at $\sim 100, \sim 1,000$, and $\sim 10,000 \mu \mathrm{U} /$ $\mathrm{ml}$. The other four underwent two tests (one after placebo and one after prednisone at $\sim 100 \mu \mathrm{U} / \mathrm{ml}$ ). Insulin binding and glucose transport on isolated fat cells were also studied in 12 males and 4 females aged $40 \pm 8 \mathrm{yr}, 98 \pm 4 \%$ ideal body weight, with no family history of diabetes, operated for cholelithiasis. The females were studied in the first $2 \mathrm{wk}$ of the menstrual cycle. Prednisone was given before surgery (same protocol) in six cases and placebo in 10 cases. No marked differences were found between the treated subjects and the controls with regard to their eating habits and physical activity in the months before the study. Physical activity was moderate in each case. Cholecystectomy was elective and not a matter of urgency. There was no evidence of inflammatory or infectious disease. The period of hospitalisation before surgery was $1 \mathrm{wk}$ in all cases. During this time, the patients were not confined to bed, and engaged in moderate physical exercise.

No other drug was administered in the previous month. During the study, diet was balanced in all subjects ( $30 \mathrm{kcal} /$ $\mathrm{kg}, 50 \%$ carbohydrates, $30 \%$ fats, $20 \%$ proteins). Informed consent was obtained from all subjects.

Test procedure. All studies were carried out at 8 a.m. after a 12-h overnight fast. The glucose clamp was started after continuous infusion of $60 \mu \mathrm{Ci} / \mathrm{h} \mathrm{D}-\left[3{ }^{3} \mathrm{H}\right] \mathrm{glucose}$ (Amersham, United Kingdom) for $\mathbf{2}$; this was continued throughout the clamp. Steady state plasma insulin of $\sim 100, \sim 1,000$, and $\sim 10,000 \mu \mathrm{U} / \mathrm{ml}$ were obtained by infusing 40,372 , and $1,280 \mathrm{mU} / \mathrm{m}^{2}$ per min prompt insulin (regular, Eli Lilly \& Co., Indianapolis, IN), respectively. In the first $10 \mathrm{~min}$, the insulin dose was augmented according to De Fronzo et al. (14) and infusion was continued for $2 \mathrm{~h}$. Blood glucose was kept at $\pm 5 \%$ of the fasting value by automatic infusion of a $30 \%$ dextrose solution through a Biostator (CGIIS, Ames, Elkhart, IN). Blood was withdrawn with a double-lumen Ames catheter in a wrist vein after arterialization by wrapping the hand in a thermophore at $60^{\circ} \mathrm{C}$. Blood gas analyses in test studies on blood obtained in this manner had shown a $\mathrm{PO}_{2}$ of $88 \pm 3 \mathrm{mmHg}$. An adjacent cannula in the same vein was used in the evaluation of plasma glucose and insulin. The following constants were used in the formula: Dextrose infusion rate $=\mathrm{RD}\left(\frac{\mathrm{BD}}{\mathrm{QD}}+1\right)^{4}$; where $\mathrm{BD}$ is blood glucose level at which basal dextrose infusion starts (equal to fasting blood glucose + $5 \%$ ); QD is inverse of the static gain for dextrose infusion (equal to 45); $\mathrm{RD}$ is minimal amount of dextrose infused by Biostator (equal to $0.8 \mathrm{mg} / \mathrm{kg} \times \mathrm{min}$ [clamp at $\sim 100 \mu \mathrm{U} / \mathrm{ml}], 2 \mathrm{mg} / \mathrm{kg} \times \min [$ clamp at $\sim 1,000$ $\mu \mathrm{U} / \mathrm{ml}], 3 \mathrm{mg} / \mathrm{kg} \times \min [$ clamp at $\sim 10,000 \mu \mathrm{U} / \mathrm{ml}]$ ). The dextrose infusion tube was replaced by a Baxter hemotransfusing apparatus (flow $=5 \mathrm{ml} / \mathrm{min}$ ). Potassium aspartate $(15$ and $25 \mathrm{meq} / \mathrm{h}$, respectively) was infused during the clamp at steady state plasma insulin $\sim 1,000$ and $\sim 10,000 \mu \mathrm{U} / \mathrm{ml}$ to prevent hypokalemia. Serum potassium values at the end of each clamp were not significantly different from the base lines.

Adipocytes were taken from the periumbilical subcutaneous tissue during the first few minutes of narcosis (nitrogen protoxide) (15).

Analytical procedure. Glucose levels during the in vivo test automatically measured by the Biostator were also checked on plasma every 5 min with a Beckman II glucose analyzer. Good reproducibility was obtained $(<5 \%$ variation). For calculation of all indexes, plasma glucose values were always used.

Specific plasma radioactivity during $\left[{ }^{3} \mathrm{H}\right]$ glucose infusion was determined according to Issekutz et al. (16).

Plasma insulin was measured by solid-phase antibody radioimmunoassay (RIA) (Korning Kit, Medfield, MA). Separation of adipocytes by digestion with collagenase was performed as previously described (15). Insulin binding to isolated adipocytes $\left(10^{6}\right.$ cells) was performed in Krebs-Ringer bicarbonate buffer $\mathrm{pH} 7.4$ (plus $1 \%$ bovine serum albumin) at $25^{\circ} \mathrm{C}$ in a $95: 5 \% \mathrm{O}_{2} / \mathrm{CO}_{2}$ atmosphere per $60 \mathrm{~min}$ in duplicate in the presence of $1 \mathrm{ng} / \mathrm{ml}$ monoiodoinsulin. Nonspecific binding was evaluated by subtracting radioactivity labeled to the cells in the presence of $100 \mu \mathrm{g}$ native insulin. Adipocytes were separated and radioactivity was counted as previously reported (15).

Intracellular transport of glucose was performed according to Ciaraldi et al. (11). Briefly, cells were preincubated for $60 \mathrm{~min}$ at $37^{\circ} \mathrm{C}$ in the presence of $0-5 \mathrm{ng} / \mathrm{ml}$ insulin. The substrate used, 3-ortho-methyl- $\left[{ }^{14} \mathrm{C}\right]$ glucose (3-OMG, ${ }^{1}$ New England Nuclear, Boston, MA), enters the cell but is not metabolized. The reaction is blocked after $10 \mathrm{~s}$ with 0.3 $\mathrm{mM}$ cold phloretin, followed by centrifugation in silicone oil. The glucose space is corrected by a parallel study with L- $\left[{ }^{14} \mathrm{C}\right]$ glucose (Amersham).

Calculations. Endogenous glucose production (milligrams per killogram per minute) was determined from Steele's formula (17). Fasting glucose production was calculated from the specific activity value (counts per minute per milliliter) of plasma glucose during the 110-120-min period of $\left[{ }^{3} \mathrm{H}\right]$ glucose infusion (steady state). Glucose production during the clamp was determined by subtracting the amount of dextrose infused from the isotopically determined total glucose production rate (endogenously produced plus exogenously infused). Negative glucose production values were treated as $0(13,18)$. The amount of dextrose infused (milligrams per kilogram per minute) was calculated every $5 \mathrm{~min}$. The

\footnotetext{
${ }^{1}$ Abbreviations used in this paper: 3-OMG, 3-orthomethyl-[1-14 C]glucose.
} 
glucose metabolic clearance rate (milliliter per kilogram per minute) was used to assess peripheral sensitivity to insulin. Since the euglycemic steady state was almost exactly the same in the three groups of tests, preference was given to Verdonk's method for the calculation of glucose metabolic clearance rate (19): De Fronzo's $M_{20-120}$ index (milligram per kilogram per minute) (14) was divided by the mean blood glucose value (milligram per milliliter). When the glucose production during the clamp was $>0$, this value was added to the $M$ index in calculating the metabolic clearance rate.

Insulin metabolic clearance rate (milliliter per kilogram per minute) was calculated at all three steady state plasma insulin levels according to De Fronzo et al. (14), namely: insulin infusion rate/increase in plasma insulin above the base line. This formula was used because plasma C-peptide measured at $30,60,90$, and $120 \mathrm{~min}$ during insulin infusion was $<0.5 \mathrm{ng} / \mathrm{ml}$ (RIA, Byk-Mallinckrodt Inc., St. Louis, MO). During the $\sim 100 \mu \mathrm{U} / \mathrm{ml}$ clamp, the insulin basal systemic delivery rate (milliunits per kilogram per minute) was calculated by multiplying the insulin metabolic clearance rate by the basal plasma insulin/1,000 according to Mc Guire et al. $(20)$.

All values were expressed as means \pm SEM. The $t$ test was used to compare the means obtained after placebo and prednisone.

\section{RESULTS}

Blood glucose and plasma insulin values after placebo and prednisone are shown in Table I. If fasting plasma glucose and insulin values are considered as a whole, it appears that prednisone was responsible for a significant $(P<0.01)$ increase in both plasma glucose $(89.5 \pm 2.1$ vs. $83.7 \pm 1.9 \mathrm{mg} / \mathrm{dl})$ and insulin $(17.8 \pm 1.2$ vs. $14.3 \pm 0.8 \mu \mathrm{U} / \mathrm{ml}$ ), whereas values during steady state plasma insulin were not significantly different after placebo and prednisone. Mean values of plasma glucose, plasma insulin, and dextrose infusion rate during euglycemic clamp at all three steady state plasma insulin levels are reported in Fig. 1. $\mathrm{M}_{20-120}$ values were significantly lower $(P<0.001)$ after prednisone at steady state plasma insulin level: $\sim 100 \mu \mathrm{U} / \mathrm{ml}(2.5 \pm 0.2$ vs. $6.1 \pm 0.5 \mathrm{mg} / \mathrm{kg}$ per $\mathrm{min}), \sim 1,000 \mu \mathrm{U} / \mathrm{ml}(4.9 \pm 0.2$ vs. $11.1 \pm 0.6)$, and $\sim 10,000 \mu \mathrm{U} / \mathrm{ml}(7.2 \pm 0.2$ vs. $13.4 \pm 0.4)$.

Glucose metabolic clearance rate (milliliter per kilogram per minute) was also significantly $(P<0.001)$ reduced after prednisone at all three steady state plasma insulin levels (Fig. 2): $2.8 \pm 0.3$ vs. $7.4 \pm 1.1$ at $\sim 100$ $\mu \mathrm{U} / \mathrm{ml} ; 6.0 \pm 0.5$ vs. $12.2 \pm 1.1$ at $\sim 1,000 \mu \mathrm{U} / \mathrm{ml} ; 7.4 \pm 0.6$ vs. $14.4 \pm 0.5$ at $\sim 10,000 \mu \mathrm{U} / \mathrm{ml}$. Fasting glucose production was significantly increased after prednisone: $3.7 \pm 0.2$ vs. $2.9 \pm 0.2 \mathrm{mg} / \mathrm{kg}$ per $\min (P<0.01)$ (Fig. 3 ). Suppression of glucose production was never complete during steady state plasma insulin level of $\sim 100$ $\mu \mathrm{U} / \mathrm{ml}$ after prednisone $(1.01 \pm 0.35 \mathrm{vs} .0 .14 \pm 0.13 \mathrm{mg} /$ $\mathrm{kg}$ per min, NS), whereas total suppression after both placebo and prednisone was observed at steady state plasma insulin levels of $\sim 1,000$ and $\sim 10,000 \mu \mathrm{U} / \mathrm{ml}$. The increase in insulin basal systemic delivery rate after prednisone was not significant: $0.23 \pm 0.02$ vs. $0.19 \pm 0.01 \mathrm{mU} / \mathrm{kg}$ per $\mathrm{min}$. The change in insulin metabolic clearance rate after prednisone was not significant: $14.3 \pm 0.7$ vs. $13.9 \pm 0.7 \mathrm{ml} / \mathrm{kg}$ per $\min$ at $\sim 100$ $\mu \mathrm{U} / \mathrm{ml} ; 10.1 \pm 0.7$ vs. $12.1 \pm 0.8$ at $\sim 1,000 \mu \mathrm{U} / \mathrm{ml}$ and $3.6 \pm 0.2$ vs. $3.7 \pm 0.3$ at $\sim 10,000 \mu \mathrm{U} / \mathrm{ml}$. Specific insulin binding was determined at only one level of insulin concentration, owing to the difficulty of obtaining enough fat for the study of the glucose transport and the competition curve. It was much the same after prednisone and placebo (4.45 vs. $4.48 \%$ ) (Fig. 4). Glucose transport is illustrated in Fig. 5. There is a significant decrease after prednisone not only at the base line (absence of insulin) $(0.40 \pm 0.10 \mathrm{vs.} 0.54 \pm 0.12 \mathrm{pmol} /$ $10^{5}$ cells, $P<0.05$ ), but also at increasing insulin concentrations (Fig. $5 \mathrm{~A}$ ). The kinetics of glucose transport is significantly different up to the maximum insulin stimulation of transport $(5 \mathrm{ng} / \mathrm{ml}): 0.59 \pm 0.04 \mathrm{vs}$. $0.92 \pm 0.12 \mathrm{pmol} / 10^{5}$ cells, $P<0.005$. The percentage of the maximal response was much the same after placebo and prednisone (Fig. $5 \mathrm{~B}$ ), whereas the percent increase over basal transport was lower after prednisone at insulin concentrations of $0.5 \mathrm{ng} / \mathrm{ml}$ (Fig. 5 C).

\section{DISCUSSION}

These results suggest that an average antiinflammatory dose of prednisone administered for $7 \mathrm{~d}$ induces insulin resistance characterized by depressed peripheral uti-

TABLE I

\begin{tabular}{|c|c|c|c|c|c|c|c|c|c|c|c|c|}
\hline & \multicolumn{3}{|c|}{$\begin{array}{l}\text { Fasting plasma glucose } \\
\text { before clamp }\end{array}$} & \multicolumn{3}{|c|}{$\begin{array}{l}\text { Steady state plasma glucose clamp } \\
\qquad 20-120 \mathrm{~min}\end{array}$} & \multicolumn{3}{|c|}{$\begin{array}{l}\text { Fasting plasma insulin } \\
\text { before clamp }\end{array}$} & \multicolumn{3}{|c|}{$\begin{array}{l}\text { Steady state plasma insulin clamp } \\
\qquad 20-120 \mathrm{~min}\end{array}$} \\
\hline & $\mathbf{A}$ & B & C & $\mathbf{A}$ & B & C & $\mathbf{A}$ & B & C & $\mathbf{A}$ & B & C \\
\hline & \multicolumn{6}{|c|}{$m g / d l$} & \multicolumn{6}{|c|}{$\mu U / m l$} \\
\hline Placebo & $81.5 \pm 3.1$ & $80.6 \pm 2.1$ & $80.3 \pm 2.8$ & $85.1 \pm 3.9$ & $91.3 \pm 6.4$ & $83.1 \pm 3.7$ & $14.4 \pm 1.0$ & $11.0 \pm 1.0$ & $16.0 \pm 1.7$ & $90.8 \pm 4.2$ & $1001.6 \pm 68.5$ & $10106.8 \pm 294.9$ \\
\hline \multirow[t]{2}{*}{ Prednisone } & $85.9 \pm 2.2$ & $89.3 \pm 3.2$ & $95.6 \pm 5.8$ & $88.6 \pm 4.0$ & $83.1 \pm 4.5$ & $98.0 \pm 4.1$ & $17.7 \pm 1.4$ & $13.7 \pm 1.5$ & $20.6 \pm 2.4$ & $100.3 \pm 3.6$ & $1108.8 \pm 45.9$ & $10236.8 \pm 367.6$ \\
\hline & NS & $P<0.05$ & NS & NS & NS & NS & $P<0.05$ & NS & NS & NS & NS & NS \\
\hline
\end{tabular}

Clamp at the steady state plasma insulin concentration of: $A=\sim 100 \mu \mathrm{U} / \mathrm{ml} ; B=\sim 1,000 \mu \mathrm{U} / \mathrm{ml} ; C=\sim 10,000 \mu \mathrm{U} / \mathrm{ml}$. 

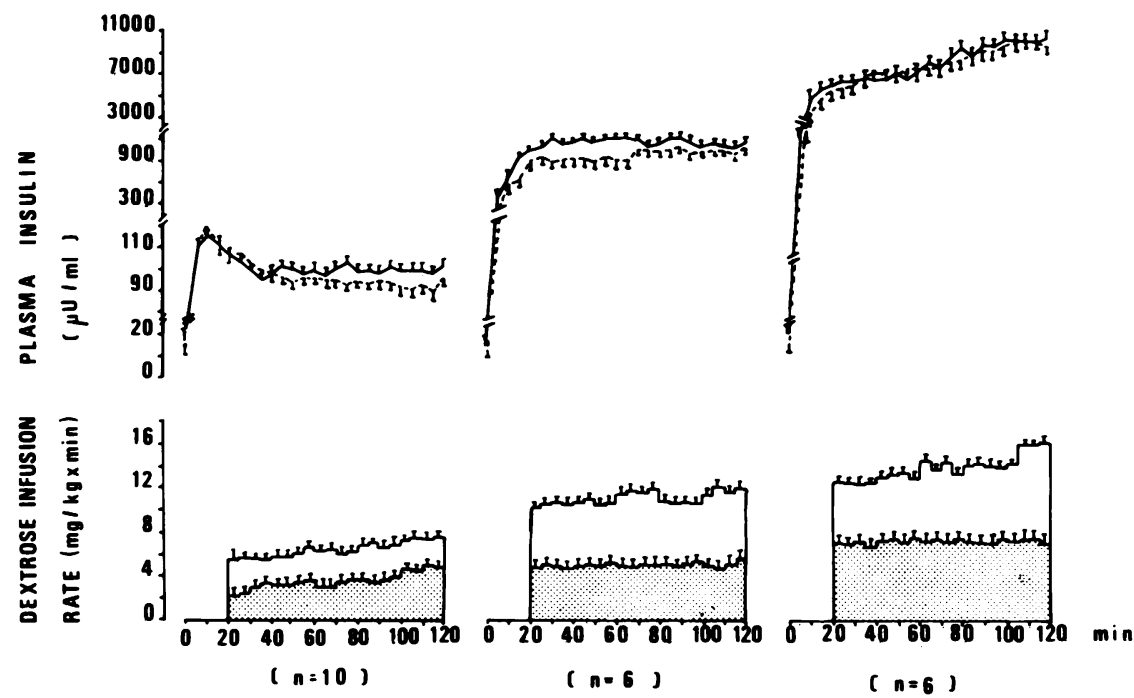

Figure 1 Euglycemic clamp. Plasma glucose $(B G)$, plasma insulin, and dextrose inf usion rate (mean \pm SEM) during euglycemic clamp at $\sim 100, \sim 1,000$, and $\sim 10,000 \mu \mathrm{U} / \mathrm{ml}$ plasma insulin concentration, after placebo $(-, \square)$ or 7 -d prednisone $(15$ plus $15 \mathrm{mg} / \mathrm{d})(---, \square)$.

lization of glucose (metabolic clearance rate) and increased hepatic glucose production in healthy subjects, as observed by Rizza et al. (6) during continuous infusion of cortisol. The significant reduction in glucose metabolic clearance rate after prednisone at steady state plasma insulin, $\sim 100, \sim 1,000$, and $\sim 10,000 \mu \mathrm{U} / \mathrm{ml}$, points to both a depressed response (reduction of maximum effect) and reduced sensitivity (rightward shift

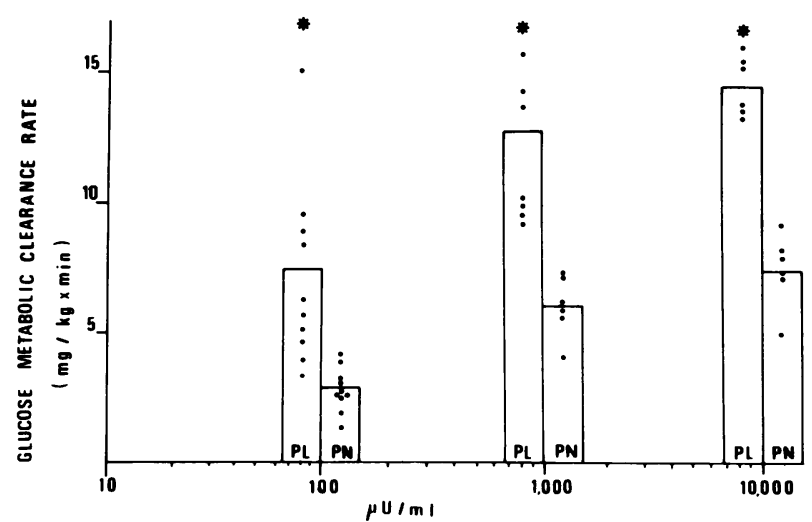

Figure 2 Glucose metabolic clearance rate. Metabolic clearance rate of glucose during hyperinsulinemic steady state $(\sim 100, \sim 1,000$ and $\sim 10,000 \mu \mathrm{U} / \mathrm{ml})$ of euglycemic clamp expresses peripheral insulin sensitivity (19) after placebo $(P L)$ or 7 -d prednisone $(P N)(15$ plus $15 \mathrm{mg} / \mathrm{d})$. ${ }^{\circ}, P$ $<0.001$. of the dose-response curve). According to Kahn's model (7), therefore, it can be supposed that the defect is both receptor and postreceptor as also suggested by Rizza et al. (6). Fasting glucose production in our study ap-

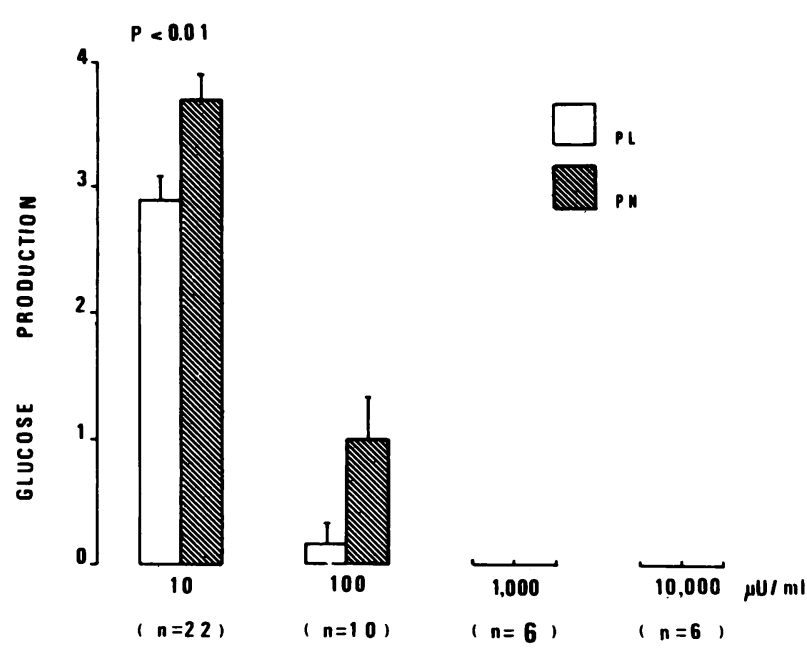

Figure 3 Glucose production (milligrams per killogram $\times$ minute). Endogenous glucose production assessed by $\left[{ }^{3} \mathrm{H}\right]$ glucose infusion $(17)$ and calculated during fasting $(\sim 10$ $\mu \mathrm{U} / \mathrm{ml}$ plasma insulin concentration) and hyperinsulinemic steady state $(\sim 100, \sim 1,000$, and $\sim 10,000 \mu \mathrm{U} / \mathrm{ml})$ after placebo $(P L)$ or $7-\mathrm{d}$ prednisone $(P N)(15$ plus $15 \mathrm{mg} / \mathrm{d})$. mean \pm SEM. 


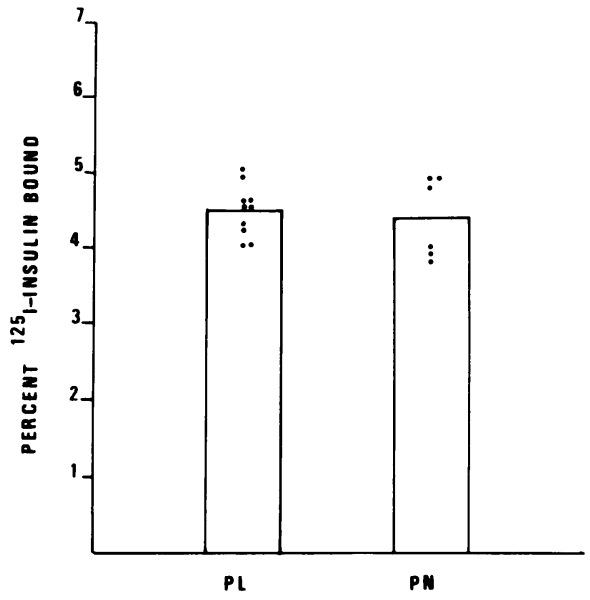

Figure 4 Insulin binding. In vitro percent specific insulin binding (15) to isolated adipocytes in the presence of $1 \mathrm{ng} /$ $\mathrm{ml}$ insulin after placebo $(P L)$ and 7 -d prednisone $(P N)(15$ plus $15 \mathrm{mg} / \mathrm{d}$ ).

pears to be significantly increased after prednisone in spite of an increase in plasma insulin. It is clear, therefore, that prednisone also promotes insulin resistance at the hepatic level. The decrease in glucose production following intravenous insulin was quite the same in the two groups (basal minus $100 \mu \mathrm{U} / \mathrm{ml}$ glucose production), indicating that this insulin dose is too high to show the insulin resistance at the hepatic level. Other authors (6) used a lower insulin concentration $(40 \mu \mathrm{U} /$ $\mathrm{ml}$ ) to study this phenomenon. The hepatic glucose production was totally suppressed at $\sim 1,000$ and $\sim 10,000 \mu \mathrm{U} / \mathrm{ml}$ steady state plasma insulin in both groups. At the hepatic level, therefore, reduced sensitivity to exogenous insulin (rightward shift of the doseresponse curve) is unaccompanied by a change in the maximum effect.

This finding is quantitatively different from that obtained by Rizza et al. (6), indicating that 7 -d prednisone administration, unlike acute infusion of cortisol, influences the insulin action in the periphery more than in the liver.

Further information on the hyperglycemic effect of prednisone was obtained by the in vitro study of insulin's effects on fat cells. These cells were studied because they are known targets of both insulin $(8,9)$ and steroids. As stated earlier, binding was studied at only one concentration $(1 \mathrm{ng} / \mathrm{ml})$ of insulin, owing to the difficulty of performing complete binding in parallel with the study of 3-OMG transport. The percentage of bound insulin was virtually the same after prednisone and placebo. The literature on this subject is conflicting in that there have been reports of an increase $(8,21)$, a decrease (22), or no change (23) in the number of insulin receptors, or a change in receptor affinity (24) after steroid administration. A decrease in total insulin receptors on liver cells after short-term dexamethasone administration in rats was reported by Caro and Amatruda (25), whereas a normal insulin receptor together

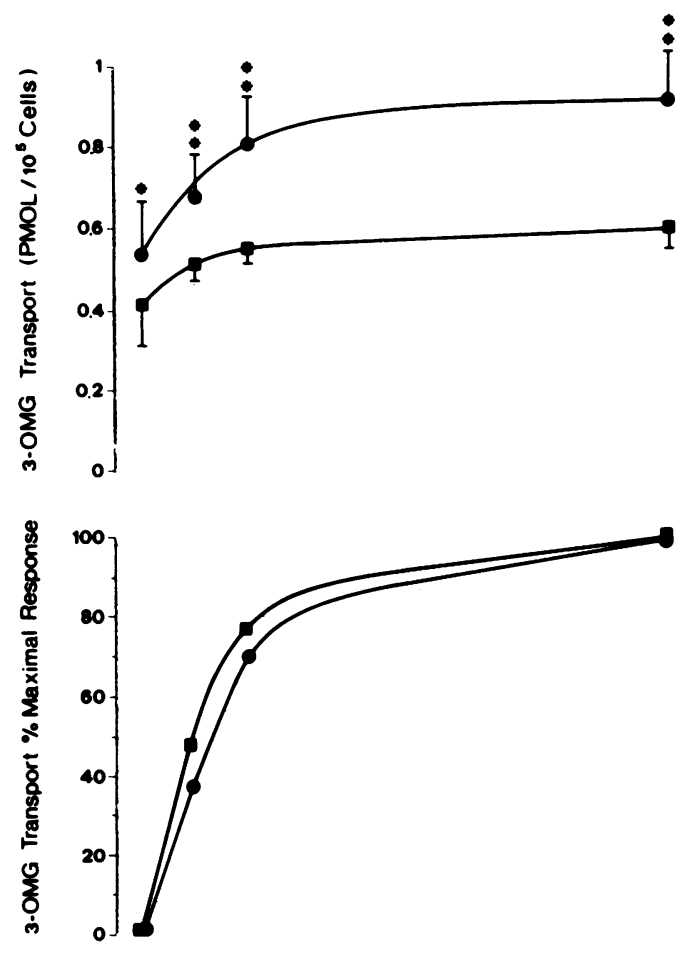

A

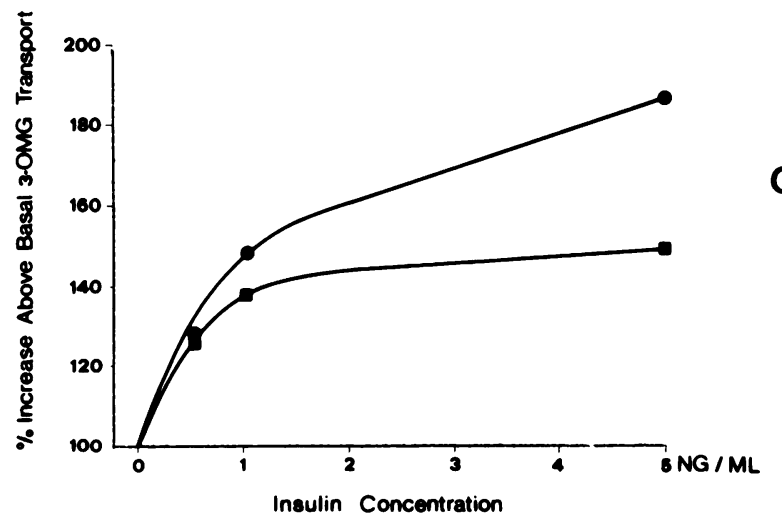

Figure 5 Glucose transport. (A) Data of 3-OMG transport rate in isolated adipocytes from 10 subjects after placebo $(\bullet)$ and $7-d$ prednisone (15 plus $15 \mathrm{mg} / \mathrm{d})$ (D). Mean $\pm S E M$. $\circ P<0.05, \cdots P<0.005$. Cells were preincubated for $60 \mathrm{~min}$. at $37^{\circ} \mathrm{C}$ at the indicated concentration of insulin, and the initial rate of 3-OMG transport was measured. All values are corrected for the L-glucose space (11). (B) Glucose transport data are expressed as a percentage of the maximal insulin effect. (C) Glucose transport data are expressed as a percentage of increase over basal transport (without insulin). 
with postreceptor defect(s) was observed after longterm treatment. Fantus et al. (8), however, in an in vitro study of insulin binding to IM-9 cultured human lymphocytes found that corticoids enhance insulin binding in vitro, whereas hyperinsulinemia in vivo leads to a reduction in the number of receptors. Thus, the type of drug and its dose and the duration of treatment will determine which of these phenomena prevails.

A further comment may be added in the light of the criticisms leveled by Klotz (26) against application of the Scatchard analysis to in vitro models. In his opinion, the graphic method on which determination of both the number of receptors and the affinity constants is based is imprecise and subject to variations. From this it may be deduced that the discrepancies observed in the literature may also have a technical explanation. In the absence of a sound alternative method, therefore, we feel it prudent to report the total specific binding percentage, even though it is clear that this cannot distinguish a change in the number of receptors from a change in their affinity. The outcome is that our measurement is the result of two phenomena (affinity and number) that may be the subject of opposing changes. Insulin binding, therefore, is not significantly altered by $7-\mathrm{d}$ treatment with $30 \mathrm{mg} / \mathrm{d}$ prednisone, though a variation in affinity as suggested by Yasuda and Kitabchi (27) cannot be ruled out. In addition, insulin sensitivity of 3-OMG transport in fat cells was much the same after both placebo and prednisone (Fig. $5 \mathrm{~B})$. Glucose transport is significantly reduced in the basal state as well as in the presence of insulin up to $5 \mathrm{ng} / \mathrm{ml}$ (maximum effective concentration of insulin added in vitro) (Fig. 5, $A$ and $C$ ). This is clear evidence of postreceptor defect, in line with our data in vivo and the deduction of Rizza et al. (6). The existence of a 3-OMG transport defect could be ascribed to the nonavailability of the specific carrier described by Czech (28). According to other workers $(29,30)$, energyand hormone-dependent translocation of the carrier systems takes place from a pool of intracellular membranes to the plasma membrane.

Since steroids, after binding to cytoplasmic receptors, signal the nucleus (9) and modify cellular enzyme activities (10), they may have either a direct or indirect effect on the glucose transport system. Evidence in favor of a direct effect can be seen in the results of Olefsky's study (31); dexamethasone action in rat adipocytes is not due to nonspecific binding to the plasma membrane but to specific reaction with an intracellular receptor. The possibility of an indirect effect, however, cannot be entirely ruled out. This could be due, for example, to the decrease in contrainsular hormones postulated by some workers (32), or to a change in intermediary metabolism, as yet undefined. Lastly, emphasis may be placed on the fact that our in vitro finding partially conflicts with our in vivo results. Thus, in vitro we observed only a reduction of the maximum biological effect, whereas in vivo the reduction of the maximum biologic effect is associated with a rightward shift of the dose-response curve. This discrepancy may perhaps depend on a different pattern of insulin binding in different tissues. Caro and Amatruda (25), in fact, have shown that cells from various tissues, or the same cells under different metabolic conditions, may respond in different ways to regulation of their receptor by the hormone (25).

It is clear, therefore, that further work is required on the interaction between corticosteroids and insulin effects not only in different cells (especially liver and muscle tissue), but also in intracellular sites. These are at present difficult to study, particularly in man. Nevertheless, they attract the greatest interest, since they are probably more influenced by the direct than the indirect effects of steroids.

\section{ACKNOWLEDGMENT}

This work was supported by a grant from the Consiglio Nazionale delle Ricerche, Rome, Italy (contract N. CT $81.00300 .04)$.

\section{REFERENCES}

1. Conn, J. W., and S. S. Fajans. 1956. Symposium on diabetes influence of adrenal cortical steroids on carbohydrate metabolism in man. Metab. Clin. Exp. 5:114121.

2. Issekutz, B., and M. Allen. 1972. Effect of catecholamines and methylprednisolone on carbohydrate metabolism of dogs. Metab. Clin. Exp. 21:48-51.

3. Kahn, C. R., K. Megyesi, R. S. Bar, R. C. Eastman, and J. S. Flier. 1977. Receptors for peptide hormones. New insights into the pathophysiology of disease states in man. Ann. Intern. Med. 86:205-211.

4. Munck, A. 1971. Glucocorticoid inhibition of glucose uptake by peripheral tissues: old and new evidence, molecular mechanism, and physiological significance. Perspect. Biol. Med. 14:265-271.

5. Owen, O. E., and G. F. Cahill. 1973. Metabolic effects of exogenous glucocorticoids in fasted man. J. Clin. Invest. 52:2596-2600.

6. Rizza, A. R., L. J. Mandarino, and J. E. Gerich. 1982. Cortisol-induced insulin resistance in man: impaired suppression of glucose production and stimulation of glucose utilization due to a postreceptor defect of insulin action. J. Clin. Endocrinol. Metab. 54:131-138.

7. Kahn, C. 1978. Insulin resistance, insulin insensitivity, and insulin unresponsiveness: a necessary distinction. Metab. Clin. Exp. 27:1893-1899.

8. Fantus, I. J., J. Ryan, N. Hizuka, and P. Gorden. 1981. The effects of glucocorticoids on the insulin receptor: an in vivo and in vitro study. J. Clin. Endocrinol. Metab. 52:953-960.

9. Baxter, J. D. 1979. Hormone receptors. N. Engl. J. Med. 301:1149-61.

10. Gorski, J., and F. Gannon. 1976. Current models of steroid hormone action: a critique. Annu. Rev. Physiol. 38:425-450. 
11. Ciaraldi, T. P., O. G. Kolterman, J. A. Siegel, and J. M. Olefsky. 1979. Insulin stimulated glucose transport in human adipocytes. Am. J. Physiol. 236:E621-E625.

12. Kolterman, O. G., R. S. Gray, J. Griffin, P. Burstein, and J. Insel. (1981). Receptor and postreceptor defects contribute to the insulin resistance in noninsulin-dependent diabetes mellitus. J. Clin. Invest. 68:957-969.

13. Rizza, R., P. Cryer, W. Haymond, and J. Gerich. 1980. Adrenergic mechanisms for the effect of epinephrine on glucose production and clearance in man. J. Clin. Invest. 65:682-689.

14. De Fronzo, R. A., J. D. Tobin, and R. Andres. 1979. Glucose clamp technique: a method for quantifying insulin secretion and resistance. Am. J. Physiol. 237(3):E214-E222.

15. Pagano, G., M. Cassader, and G. Lenti. 1977. Insulin receptors in adipocytes of nondiabetic and diabetic subjects. Preliminary report. Acta Diabetol. Lat. 14:164169.

16. Issekutz, B. J., M. Allen, and I. Borkow. 1972. Estimation of glucose turnover in the dog with glucose-2-T and glucose-U- ${ }^{14} \mathrm{C}$. Am. J. Physiol. 222:710-712.

17. Steele, R., J. Wall, R. De Bodo, and N. Altszuler. 1956. Measurement of size and turnover rate of body glucose pool by the isotope dilution method. Am. J. Physiol. 187:15-19.

18. Greenfield, M. S., L. Doberne, M. Rosenthal, B. Schultz, A. Widstrom, and G. M. Reaven. 1982. Effect of sulphonylurea treatment on in vivo insulin secretion and action in patients with non-insulin-dependent diabetes mellitus. Diabetes. 31:307-312.

19. Verdonk, C., R. Rizza, and J. Gerich. 1981. Effect of plasma glucose concentration on glucose utilization and glucose clearance in normal man. Diabetes. 30:535-540.

20. Mc Guire, E., J. D. Tobin, M. Berman, and R. Andres. 1979. Kinetics of native insulin in diabetic, obese, and aged man. Diabetes. 28:110-120.

21. Beck-Nielsen, H., R. De Pirro and O. Pedersen. 1980. Prednisone increases the number of insulin receptors on monocytes from normal subjects. J. Clin. Endocrinol. Metab. 50:1-4.

22. De Pirro, R., A. Bertoli, A. Fusco, I. Testa, A. V. Greco, and R. Lauro. 1980. Effect of dexamethasone and cortisone on insulin receptors in normal human male. $J$. Clin. Endocrinol. Metab. 51:503-507.

23. Shamoon H., V. Soman, and R. Sherwin. 1980. The influence of acute physiologic increment of cortisol on fuel metabolism and insulin binding to monocytes in normal humans. J. Clin. Endocrinol. Metab. 50:495-502.

24. Kahn, C. R., I. D. Goldfine, D. M. Neville, and P. De Meyts. 1978. Alterations in insulin binding induced by changes in vivo in the levels of glucocorticoids and growth hormone. Endocrinology. 103:1054-1066.

25. Caro, J. F., and J. M. Amatruda. 1982. Glucocorticoidinduced insulin resistance. J. Clin. Invest. 69:866-875.

26. Klotz, I. M. 1982. Numbers of receptor sites from Scatchard graphs: facts and fantasies. Science (Wash. DC). 217:1247-1249.

27. Yasuda, K., and A. E. Kitabchi. 1980. Decreased insulin binding of human erythrocytes after dexamethasone or prednisone ingestion. Diabetes. 29:811-814.

28. Czech, M. P. 1980. Insulin action and the regulation of hexose transport. Diabetes. 29:399-409.

29. Cushman, S. W., and L. J. Wardzala. 1980. Mechanism of insulin action on glucose transport in the isolated rat adipose cell. Apparent translocation of intracellular transport systems to the plasma membrane. J. Biol. Chem. 255:4758-4762.

30. Suzuki, K., and T. Kono. 1980. Evidence that insulin causes translocation of glucose transport activity to the plasma membrane from an intracellular storage site. Proc. Natl. Acad. Sci. USA. 77:2542-2545.

31. Olefsky, J. M. 1975. Effect of dexamethasone on insulin binding, glucose transport, and glucose oxidation of isolated rat adipocytes. J. Clin. Invest. 56:1499-1508.

32. Marco, J., C. Calle, D. Roman, M. Diaz-Fierroz, M. Villanueva and I. Valverde. 1973. Hyperglucagonism induced by glucocorticoid treatment in man. N. Engl. J. Med. 288:128-131. 